\title{
A narrowing of meaning: loss of narrative unity and the nature of design change
}

\author{
Stuart Walker \\ Faculty of Arts and Social Sciences, \\ Lancaster University, \\ The Roundhouse, Lancaster LA1 4YW, UK \\ Email: s.walker@lancaster.ac.uk
}

\begin{abstract}
This paper seeks to explore where design might best focus its efforts with respect to contemporary concerns about sustainability, particularly in view of the magnitude and nature of change required. The discussion traces the long entrenchment, over several centuries, of assumptions, conventions and outlooks that resulted in a shift in worldview from traditional to modern/late-modern. This shift is not only associated with unprecedented environmental damage, but also with a narrower perspective, a loss of narrative unity, and a loss of meaning. The argument is made that, by focussing on rationalistic, techno-scientific solutions design restricts its contribution to a variety of incremental changes that actually support the continuance of a fundamentally unsustainable system. Instead, design can widen its purview and be a catalyst for more substantive change by restoring a more balanced approach to products and processes in context; thereby contributing to a recovery of narrative unity and meaning.
\end{abstract}

Keywords: unsustainable worldview; global-local; rational and intuitive; narrative unity; design.

Reference to this paper should be made as follows: Walker, S. (2014) 'A narrowing of meaning: loss of narrative unity and the nature of design change', Int. J. Sustainable Design, Vol. 2, No. 4, pp.283-296.

Biographical notes: Stuart Walker is Professor of Design for Sustainability and Co-Director of the Imagination Lancaster Research Centre at Lancaster University, UK. He is also a Visiting Professor of Sustainable Design at Kingston University, UK, Adjunct Professor at Ontario College of Art University, Toronto and Emeritus Professor at the University of Calgary, Canada. His research papers have been published and presented internationally and his conceptual designs have been exhibited at the Design Museum, London, across Canada and in Italy. His books include: Sustainable by Design: Explorations in Theory and Practice, 2006; The Spirit of Design: Objects, Environment and Meaning, 2011; The Handbook of Design for Sustainability, 2013, and Designing Sustainability: Making Radical Changes in A Material World, 2014.

\section{Introduction}

In this discussion, I consider the magnitude and nature of change required to address contemporary environmental and social concerns, and the potential role of design in 
contributing to such change. Current attitudes, expectations and societal norms are shown to be the result of long established conventions and priorities. These are proving extremely resilient, despite the apparent need for urgent reform. While not underestimating the scale of the challenge, the discipline of design - as an applied art that draws upon the human imagination and valorises creativity ${ }^{1}$ - has the opportunity to play an important part in manifesting alternatives and demonstrating, through concrete design propositions, new ways forward. In doing so, and if informed by philosophical, ethical and environmental considerations, design can make a constructive contribution to the nature, extent and pace of positive change.

The development of what we might refer to as 'the modern sensibility' began perhaps as early as the 1400 s and continued undiminished well into the 20th century. The long progression of discoveries and changing understandings that occurred during this period yielded a set of attitudes, outlooks and a worldview that were quite different from those of the earlier, pre-modern era. Over time, assumptions, conventions and societal norms became consolidated and the modern worldview became deeply rooted and institutionalised.

As a consequence of this entrenchment, and despite many countervailing influences and accomplishments over recent decades, modernity's overarching priorities remain largely unaffected and the direction of Western development continues apace. In the 21 st century, for example, the perpetuation of exploitative, seriously harmful practices is justified primarily on economic grounds in the interest of maintaining competitiveness. This is exactly the same justification given for the perpetuation of exploitative, seriously harmful practices in the 17th century. Three hundred years ago these were slavery practices associated with international colonisations, and politicians argued that any change would be economically ruinous and would allow other countries to benefit [Hague, (2007), p.172; Schama, (2009a), p.334]. Today, they are slave-like labour practices associated with international corporations, as well as practices that cause environmental degradation, and politicians continue to make essentially the same argument (Gray, 2012).

Perceptions that were centuries in the making, that are bolstered by convention and fortified by political, economic, and educational policies are unlikely to be transformed in just a few decades. However, it is these very attitudes and outlooks that are so strongly associated with the domination and exploitation of the natural environment and potentially hazardous effects on biodiversity and climate; with social injustices, division and disparity; and with a prevailing sense of un-ease and anxiety about the future. All these things are part and parcel of contemporary notions of sustainability. Yet, even though the modern sensibility has been much debated and much criticised since the mid-20th century, its essential features persist - not only because of their long period of gestation but also because no practical, desirable alternative has yet emerged. What is more, unlike the transition from the medieval to the modern, today we do not have centuries to develop a systemically different course. Therefore, it behoves us all including designers - to consider how new, more fruitful directions may be nurtured and encouraged.

To better understand the nature of the modern sensibility, and thence the significance of the change that is needed, it becomes important to trace its development and establishment. Then we can begin to recognise it for what it is, and how it differs from a sensibility that is in greater alignment with current notions of sustainability. It is clear that design change, along with broader societal change, is only likely to come about if 
current market-led/consumption-based directions are drastically curtailed. This will require far more effective and emphatic political leadership than has been evident of late among the liberal democratic governments of Western nations. Such leadership will necessarily have to focus on longer term interests that serve the common good rather than short term interests that serve electoral ambitions and myopic ideas about winning in an economic 'global race' (Beckett, 2013). A new sustainable realisation is needed and new kinds of material culture will have to be designed that help strengthen the common good of regions, nations and the global community. A critical ingredient of this will be ways of living that accord with human flourishing while ensuring very significant reductions in overall levels of consumption.

\section{The equanimity of wisdom}

There is evidence to suggest that in pre-modern times a fertile balance was achieved between rationalist/intellectual and imaginative/intuitive ways of thinking and understanding the world. As far back as ancient Greece, we see that advances in philosophy and the systemisation of knowledge and laws occurred alongside advances in human imagination and unsurpassed achievements in the visual arts. Here, the former emphasises intellectual, analytic thinking and requires us to become 'detached' and thus able to objectify the world around us, while the latter calls upon intuitive, synthetical thinking, which mediates this objectification, allowing us to re-connect with other people and with nature. McGilchrist explains that expansion in human knowledge and understanding during this period involved "moves in two diametrically opposed directions at once - towards greater abstraction from the world and, simultaneously, towards greater empathetic engagement with the world". He goes on to explain that if we pay attention to our real, engaged experiences, rather than abstract notions of the world, we encounter the coming together of these apparent opposites. Indeed, traditionally this reconciliation was considered to be the basis of wisdom [McGilchrist, (2009), pp.259-269]. However, by the late medieval period, a decline in metaphoric and symbolic understandings meant that many traditional ideas and practices had become hollow and empty (Ibid, p.314); these developments are related, also, to a weakening of the Church, which had long provided a foundation for spiritual meaning and material stability. This early-modern period witnessed a host of very significant societal changes.

\section{The birth of the modern}

With its roots in southern Europe, the Renaissance (ca. 1400s-1600s) is characterised by a self-conscious development of individuality, and the emergence of individualism and the modern identity [Tarnas, (1991), p.226]. Renaissance education, known as Humanism, included study of Latin and Greek texts, logic and rhetoric, as well as mathematics, music, science, and an interest in comprehending and mastering the natural world; all with the aim of fulfilling worldly ambitions. In its earlier years at least, it was also a period of revitalised interest in metaphor, symbolism and understandings associated with intuitive ways of knowing and the human imagination. Hence, an upswing in the arts went hand-in-hand with an emphasis on reason and logic and, 
eventually, the emergence of secularism and a rationalism that was suited to more pragmatic, worldly endeavours. It was a time of open-mindedness and broadening horizons [Armstrong, (2002), p.6; Brotton, (2006), pp.3-5; McGilchrist, (2009), pp.314-324]. A new interest in exploration led to merchant adventurers expanding trade routes to the east and searching out new opportunities to the west and the recently discovered Americas. In turn, these developments in international trade spurred improvements in business practices, many of which were imported from other cultures; new accounting methods, for example, were learned from Arabia [Brotton, (2006), pp.25-27].

However, along with these developments, from which was born a new sense of purpose and confidence, there emerged unfamiliar tensions and uncertainties. Through global expansionism, Europeans were brought in contact with other civilisations, ideas and religions [Hampson, (1968), pp.25-28]. The advent of the printing press enabled these new ideas to be widely disseminated. As a result, belief in established understandings and assumptions became less assured, and this fostered a growing sense of anxiety, doubt and dis-ease [Brotton, (2006), p.4]. These developments are also linked to discord within the Church and dissent against institutionalised religion which, in the early years of the 16 th century, resulted in the Reformation.

Hence, this period saw significant transformations in values, priorities and worldview. It gave rise to modern notions of individualism and progress, emphasised the power of reason, and established social and cultural institutions that continue to define much of the Western world today, including the notion of democratic politics. Colonisation and commerce created enormous wealth for some. It sowed the seeds of modern banking, heralded the beginnings of contemporary capitalism and established the pattern for consumer society. This period also seems to have given rise to a belief in European cultural superiority (see below).

\section{A narrowing}

Whereas the Renaissance witnessed a renewed interest in the arts and developments in intellectual thinking, philosophy and reason, the Reformation was a period characterised by a rejection of imagery, metaphor and symbolism [Fernández-Armesto and Wilson, (1996), pp.103-108; Schama, (2009b), p.267]. There was an insistence on the ostensible 'certainties' associated with rational argument, analysis and explication, all of which are associated with the intellect and predominantly left-hemisphere brain functions [McGilchrist, (2009), p.314]. With its roots in Northwestern Europe, the Reformation (ca. 1500 s to 1600s) was a time of dissent against the Catholic Church and its practices, priorities and failings. It is noticeable that the new approach to faith centred on language, words and liturgy and that the reformers encouraged a literal reading of scripture and frowned upon allegorical interpretations. The pulpit became a prominent feature of Protestant churches, and clerical control was maintained through highly vocal practices that afforded a new authority to the sermon. ${ }^{2}$ Religious imagery, accessible to all and therefore an egalitarian aid to faith, was destroyed or covered over, and more solitary, silent spiritual practices were looked upon with suspicion and generally disfavoured [Duffy, (1992), p.381; MacCulloch, (2013), pp.129-136]. Protestantism tended to stress the rationality of Christianity, in contrast to the Catholic tradition, which encompassed metaphor, symbolism and the mysteries [Hampson, (1968), p.130; Schama, (2009c), 
p.34]. Also, and uniquely in the history of Christianity, Protestantism sanctified individualism [Schama, (2009b), p.267]. Hence, these reforms can be seen as an attempt to align religion with a broader societal insistence on rationality and individualism.

The European Enlightenment (ca. 1600s to 1700s) saw these ideas become further embedded. This was a time of growing confidence in dispassionate, instrumental reason. There was a retreat from the more holistic outlooks of earlier times where rationalist/intellectual understandings were balanced with imaginative/intuitive ways of knowing. Many traditions that acknowledged this sense of interdependent completeness were prohibited. There was a new sense of capacity, power and invulnerability in humanity's ability to determine right action through reason alone, and to shape the future by controlling the material environment and the structures of society [Taylor, (2007), pp.300-301; Hampson, (1968), pp.23-29]. It was a period that sought certainty through a rejection of all those aspects of our humanness that are ambiguous, mysterious, or imaginative. Under the scrutiny of this rationalistic eye, ritual, imagery and silence, which can be rich in metaphorical meanings but do not 'explain', became impenetrable and absurd. Metaphor ceased to be integral to the conveyance of meaning, and allegorical imagery was replaced by mere signs. As a consequence, meaning became independent of form, which McGilchrist (2009, pp.315-318) identifies as 'one of the most damaging legacies' of this stage of Western development. A new authority was granted to scientific and analytical methods, utilitarianism, materialism, secularism and the ideology of individualism, and legitimate knowledge was to be grounded in provable facts. This had the effect of undermining the import of imagination, intuition and contemplation, all of which had been part of religious and spiritual practices and of notions of human wisdom for centuries.

There were some, such as Blake, who regarded such a project as "an impious denial of the sacred truth of the imagination" [Hampson, (1968), p.127]. Nonetheless, the ideas of this 'Age of Reason' took hold and, in contrast to the open-mindedness of earlier times, it resulted in a narrower view of reality. It is this narrowed view, which emphasised intellectual thinking, 'occidental rationalism' and progressive technological means, but with little idea of ends, that is concomitant with what Weber referred to as the 'disenchantment' of the modern world (Schwaabe, 2011).

These evolving understandings and changing priorities in Western society established the basis for advancement in scientific knowledge; the striving for objectivity; and developments in technology and industry in the 18th and 19th centuries. The Industrial Revolution completely transformed society. The transition from dispersed, rural, craft-style production to factories saw the rise of industrial capitalism along with massive urbanisation. Industry was gearing up for the mass-production of identical, efficiently processed consumer products. At the same time, influential voices in society were calling for an abandonment of the past [Gay, (2007), pp.13, 434; Corfield, 2008] and with it traditional sources of knowledge and wisdom.

These developments lie at the heart of today's environmental crisis and contemporary debates about sustainability. They are characterised by an instrumental approach permeated by the language of control over of nature. For instance, an eminent scientist recently encouraged school children to consider a career in science by saying, "if you like the idea that you will be the first one to ever think about something on Earth and that you might actually change Earth by doing that, you should be a scientist" (Bassler, 2014). It is important to bear in mind, too, that the 'change' enabled by scientific research, even with 
the best intentions, is developed and steered within a dominant milieu in which specialised knowledge is employed to win competitive advantage, maximise efficiencies and boost financial profits. Within the corporate milieu, the primary goal is neither social good nor environmental care but quarterly earnings [Bakan, (2004), pp.60-61].

\section{Individualism, 'superiority' and meaninglessness}

The most significant development of modernity has been the notion of individualism [Pratt et al., (2000), pp.81-84]. Indeed, the systems and institutions that arose during this period were designed to support the rights and privileges of the individual over common or collective interests. The free-market system and liberal democracy both support individualism; indeed, individualism and democracy go hand-in-hand [Chaibong, (2000), p.127]. As we have seen, these developments occurred in a time of growing interest in the intellectual power of reason, and legitimate knowledge was increasingly being linked to the findings of science [Brotton, (2006), pp.3, 114; Armstrong, (2002), p.6]. While these reforms offered new possibilities for individual and political freedom, enterprise, and wealth creation, they were also dogged by signs of dissonance and instability. There was an increasing sense of alienation, isolation and meaninglessness, which was associated with a denial of transcendence [Chaibong, (2000), p.127; Taylor, (2007), pp.561, 717].

All these developments were bound up with empire, the positional superiority that accompanied European hegemony ${ }^{3}$, and an enduring legacy of exploitation [Said, (1978), p.7; Young, (2003), pp.41, 60]. We would be remiss, therefore, to consider the achievements of modernity without also recognising the severe and lasting impacts of its associated effects. Furthermore, the rise of individualism, along with a philosophical outlook of materialism, and associated desacralisation and disenchantment of the world [Taylor, (2007), p.25], removed any moral or spiritual barriers to the exploitation of the natural environment. Significantly, many of these occurrences were based in intellectual pursuits and abstraction, and this meant that the contribution of other ways of knowing became less important, i.e., intuition, tacit knowledge and understandings based in experience [Edwards, (2012), pp.39-40].

Thus, the 'modern sensibility', despite its manifold achievements, actually represents a profound contraction and disambiguation in understandings - a narrowing of outlook that prioritises certain aspects of the human condition to the detriment of others [see also Nagel, (2012), p.4; Heidegger, (1971), p.168]. And it is this constricted view that is linked not only to enormous social and environmental impacts but also to the deep sense of meaninglessness that has always shadowed this period.

\section{Power, capitalism and bureaucracy}

Accompanying modernity's philosophical, scientific and technological developments was a will to power that became manifested in the form of capitalism and was attended by a rise in bureaucracies [McGilchrist, (2009), p.321]. Traditional understandings that recognised cycles and repetitions, offered continuity and change, and had intrinsic value either faded away or took on new guises to fit within the predominant, more pragmatic, especially market-led, rationale. 
These are the attitudes that still dominate our political, educational, and public and private sector organisations. Their bureaucratic tendencies and narrow economic priorities are illustrated in some disturbing contemporary approaches to environmental issues. For example, much effort is being put into the measurement, quantification and monetisation of nature. Under the auspices of 'ecosystem services', the aim is to allocate a financial value to streams, wetlands, species and even to the aesthetic value of vistas (e.g., Lester, 2012; Rodwell, 2013). The reliance on numbers gives the approach an appearance of neutrality and objectivity which, in reality, masks an oversimplification that is anything but objective. These attempts to use market-led modes where other, broader forms of governance are needed have "led to a dangerous collusion between entrenched financial and corporate interests, on the one hand, and entire natural ecosystems, on the other" [Fioramonti, (2014), pp.136-142]. The result is that we allocate a price to that which is priceless and Nature becomes just another commodity.

While giving precedence to such methods may be misguided, they do illustrate the sheer persistence of the unmodulated rationalistic outlook. By maintaining this outlook, we compromise our thinking and our ability to tackle the critical issues of our time. It leads to deeply distorted ideas about knowledge, the world, and the nature of the human condition and it is leading us relentlessly down a path of worsening inequity and remorseless environmental destruction.

\section{Embedded unsustainability}

From the foregoing, we see that the political and corporate agendas of contemporary Western societies are firmly established in a growth-based system that is deeply rooted in historical events and fuelled by technological advancement. It is driven by product innovation and production that are heavily - perhaps ruinously - dependent on natural resources, energy use and ever-expanding markets. On the grounds of increased consumer choice, it is a system that promotes over-production and, consequently, wastage is an inherent part of its constitution. As markets and choices expand and as disposal and replacement cycles become more rapid, demands on the earth's materials and energy resources increase. This upward trend, accompanied by similar trends in pollution and waste, shows no signs of abatement despite higher energy efficiencies and improved material intensities ${ }^{4}$ (Lutter and Giljum, 2012; UNEP, 2009).

It is also a system that has severely damaging social consequences. Firstly, the competitive individualism it promotes through the production of status-oriented 'positional goods' is insidiously socially divisive [Lansley, (1994), p.134]. Secondly, the multiplication of choices can be detrimental to individual human welfare, being linked to increased dissatisfaction, stress and depression [Schwartz, (2004), pp.109, 132-133]. Thirdly, disparities between wages have increased enormously over the last few decades ${ }^{5}$, whereas research suggests that greater equality is the route to a society improving everyone's quality of life and to a sustainable economy [Wilkinson and Pickett, (2009), pp.232, 243]. Hence, rather than being a benefit to society, this kind of consumer capitalism, which maximises the wealth of the few and fails to serve the social good, is in reality socially damaging.

Finally, and with disturbing parallels to the colonialism of former times, today's emphasis on globalisation, free trade and the export of democracy and consumer culture 
to other societies is a form of cultural imperialism that is innately inequitable - the essential premise being that the forms of governance, society, economics, and thinking developed among Western nations are incontrovertibly 'correct' and need to be adopted by all other nations, irrespective of their own traditions or points of view [Said, (2003), p.14]. As Said has said, there is "a profound difference between the will to understand [other peoples] for purposes of co-existence and humanistic enlargement of horizons, and the will to dominate for the purposes of control and external dominion" (Ibid), whether that be for political control, for resources, or for expansion of markets. Nevertheless, by invitation, persuasion or other means, the lifestyles and consumer cultures that became common in the 'developed' nations over the course of the 20th century are, in the 21st, being adopted globally. Roughly half of the world's 'consumer class' is now located in the 'developing' world (Worldwatch Institute, 2013).

There have been, and in some parts of the world there still are, ways of living that are very different from those we consider 'normal'. Rather than constantly seeking to expand our markets and influence, we in the West have the opportunity of learning from those who retain less destructive, more socially cohesive ways of living. Duffy has characterised contemporary Western society as being dominated by a system in which people are dehumanised and isolated, and that has promoted an idea of 'freedom' as unrestricted individualism. Related to this, he argues that Western society's emphasis on the acquisition of more and more knowledge will never allow us to appreciate the goodness of reality and our place in it [Duffy, (2004), pp.1-3]. To have such an appreciation, fidelity to the heritage of human wisdom is required; a heritage of insight and understanding that spans history and draws from all civilisations. There are many historical precedents that synthesise material production with social, ethical, spiritual and environmental considerations. Examples can be drawn not only from traditional societies but also from more recent practices - such as the Shakers of North America, whose elegant designs were communally produced and integrated with their spiritual beliefs [Sprigg and Larkin, (1987), p.110], and 19th century enterprises in the UK that were, notably, started by Quakers; for instance, John Cadbury's chocolate company, which combined manufacturing with social welfare and social housing projects (Bournville, n.d.). In Western society, after years of conscientiously rejecting the past as 'old hat' and looking only to the future, such an appreciation demands a new sense of humility. It also means reversing worrying trends of political interference in education curricula in which preferential support is given to those subjects deemed to be useful to the economy, and where support is withdrawn from other critical areas [Paton, 2014; Lloyd, (2013), p.4].

\section{Beyond individualism and 'progress'}

It is evidently the case that knowledge arising from investigation and rational analysis can accrue over time and that this has been the privileged form of knowledge since the early-modern period. As a result, other kinds of knowledge have tended to become excluded from the centre ground of public discourse. These other kinds of knowledge, which are important for a more balanced worldview, are not and can never be cumulative. They have to be learned by each individual in his or her journey through life. Even though these meaning-seeking, even spiritual, apprehensions seem to be a feature of our humanness [Pagels, 2006; Dworkin, (2013), pp.2-3], for the most part these kinds of knowledge are neither transferable nor shareable [Reid, (2013), p.35]. They are holistic 
rather than reductionist, concerned with subjective experiences and intuition rather than objective facts, and they enable us to synthesise the bigger picture rather than analyse its particulars. They are associated with knowledge and understandings in context, with inner values and wellbeing, and development of character, conscience and notions of rightness and goodness. It is these kinds of knowledge that can temper what we are capable of doing by giving due consideration to what we ought to be doing. However, as MacIntyre has explained, these ways of knowing are dependent on two essential concepts, narrative unity and practice. Narrative unity pertains to the individual person, the subject of a narrative that begins at birth and continues until death. It is this narrative unity that allows a person to be accountable for all the activities and decisions that make up his or her life story. It is this narrative unity that is tied to unity of character and hence to personal identity [MacIntyre, (2007), pp.218-227]. It is also the case that a person is not only accountable for their own life but, because lives are interwoven, one can ask of and be expected to be accountable to others; hence individual narratives are interrelated and interdependent. This effectively counters the ideology of individualism, which has become such a prominent feature of contemporary society, but it does not compromise the importance of personal character and individuality. Rather it recognises the relationship between individual persons, community, and society as a whole.

The unity of an individual life is the unity of the narrative which that life embodies and this is intimately related to notions of virtue and practice. It raises questions about how best to live out that unity, about how one should live, and about what is good. Practice in this context refers to activities in the world that are sustained by dispositions of virtue and goodness, which help guide us in such a way as to avoid causing harm or succumbing to impulsive desires or selfish behaviours. In turn, such practice increases our self-knowledge and our understanding of the good (Ibid).

The period of modernity tended to erode these holistic, unified notions of a human life. Areas of knowledge became divided into specialised siloes - pure and applied sciences, social sciences, fine and applied arts. Similarly, an individual's life became divided into discrete segments, each characterised by its own distinct qualities, norms and modes of behaviour - work, leisure, public life, private life, childhood, adolescence, and old age. A consequence of these moves towards compartmentalisation is that the narrative unity of an individual's life becomes lost and with it notions of personal identity, character, conscience, duty and accountability (Ibid, pp.204-227). This lack of accountability is reflected too in work practices where the division of labour fragments human activities thereby preventing holistic understandings of actions and their consequences and effectively permitting the avoidance of responsibility [Thompson, 1980; Leopold, (1949), pp.67-68].

\section{Design and the nature of change}

It is only with the enormous expansions of mass production and consumption since the mid-20th century that the tangible and severe consequences of this constricted view have become widely recognised. In this period, not only has production efficiency based on a strict economic logic become paramount but also, theoretical ideas have played an increasingly important role [Odent, (2013), p.63]; and theories are a form of rationalised abstraction that concern general rules - they do not deal with concrete realities in context. 
Design, however, is an applied discipline that does deal with concrete realities and if it is to deal with these in context, it will need to move away from its allegiance to corporate agendas aimed at 'generalised' mass production for global distribution. Approaches are required that are far more sensitive to individual needs, social and cultural diversity, the qualities of locale, and the interrelated effects of material consumption - i.e., that are appreciative of socio-cultural and environmental context. Furthermore, our ability to sympathetically elucidate design in context is dependent on the fact that, in purpose and practice, design is a discipline that is integrative. It brings together and seeks to synthesise rationality, efficiency and instrumental value with imagination, inspiration and intrinsic value. It makes use of data, reasoned argument and expert knowledge but also draws on experience, aesthetic sensitivity and tacit knowledge. By attempting to reconcile and harmonise these complementarities in context, design can contribute to a sense of narrative unity. Connections are created between human needs and tasks, materials, place, knowledge and skills, effects and implications. In this way, our activities become contextualised, comprehended and, over time, adjusted to be in accord with individual needs, social conditions, and the characteristics of place. All these help build a more profound sense of meaningfulness to our endeavours and to our material culture. These are the very things that became eroded during the period of modernity/late-modernity and they are the things that have to be restored if we are to effectively address the contemporary challenges of sustainability.

There are strong parallels here between an argument for the importance of localised design and making and Duffy's discussion about the value of folk traditions in religion. Both bear fruit that is critical for the appreciation and stewardship of nature, for collective understandings and community cohesion and, at a personal level, for a more profound sense of purpose and meaning. Papanek (1995, p.61), an earlier pioneer of design for sustainability, advocated design for small-scale, decentralised production combined with re-use to create new kinds of processes that are not only environmentally benign but also spiritually nourishing. Such approaches, which are well represented in traditional societies, are not subject to the compartmentalising of tasks, the dissipating of accountability, or the externalising of production costs such as pollution, health care and social deprivation, that otherwise could have a negative effect on the bottom line. In addition, localised, collective practices, embedded in and contributing to community, represent a strong counterpoint to contemporary individualism. They are less dependent on the points of view or feelings of the individual but are instead rooted in historical precedent and collective understandings and it is these very attributes that help contextualise the lives of individuals and in the process offer a sense of integrity, dignity, continuity and meaning [Duffy, (2004), p.18]. Not only can such practices help restore a sense of narrative unity to our lives [MacIntyre, (2007), p.227], they also raise questions about the place and importance of 'originality' in design. This quest for originality, which is clearly linked to notions of individualism and the modern sensibility, is not new. It was raised at the very start of the 20th century by Loos (1900, pp.124-127), who criticised this quest in his parody The Poor Little Rich Man.

\section{Conclusions}

Present concerns about social inequity, environmental degradation and a loss of meaning are inextricably linked to the conventions, doctrines and norms that took hold 
during the period of modernity/late-modernity. Of these, the ideology of individualism can be seen as the central accomplishment of this phase of Western thought [Chaibong, (2000), p.127]. It is apparent, too, that concerns about sustainability will not be addressed effectively by simply continuing in the same vein, perhaps with incremental adjustments here and there. The growth-oriented, consumption-based system that has come to dominate modern societies is inherently divisive, excessively dependent on natural resources and waste production, and bound up with a loss of meaning. In this light, ecosystem service models that monetise and marketise nature are a continuation of the prevailing thinking. Similarly, 'objective' numerical approaches, such as product life cycle assessment, not only mask the subjectivity of the decisionmaking involved, but also fix our attention on incremental improvements to an inherently problematic system [Fletcher, (2013), pp.287-289]. Again, the instrumental focus of design as a 'problem solving' activity that leads to improved technological solutions represents a continuation rather than a shift in thinking [Davison, (2013), p.43].

To address the challenges wrought by this overly-narrow outlook, which Nagel (2012, p.12) argues "is ripe for replacement", we have to consider a restoration of ways in which ethics and self-transcendent (beyond individualism) values and priorities can become integrated within our business practices. It becomes necessary to recognise that the dominance of reductionist, evidence-based research and rational argument can bring us only so far [Nagel, (2012), p.7] and that decision-making has to take into consideration not just what is most efficient and financially profitable within the boundaries of the law but also concerns and questions about what is meaningful and good. This amounts to a recognition of the importance of complementarities, and a restoration of the balance they imply in our outlooks and activities.

Design can contribute to this change. Fry (2009, p.3), for example, has argued that design ethics is currently grossly underdeveloped and marginal to both design practice and design education and Mau (2004) has recognised that 'massive change' is needed if we are to address the social, economic and ecological challenges of our age. A critical contribution of design will be the development of creative propositions that imbue our visual and material culture and our day-to-day activities and routines with something of those ways of knowing that have become devalued and neglected in recent times - the tacit, the intuitive, the meaningful and the profound. Among the various professions involved in the creation and production of our day-to-day material things, it is the designer who has the wherewithal and the responsibility to visually express imaginative, constructive ways forward. It is the designer, more so than the engineer or the technologist, who is trained in the studio practices of concept development, aesthetics, the skills of visualisation, and the socio-cultural aspects of material goods. It is the designer, more so that the fine artist, who is trained in the methods and limitations of industrial production and the requirements of materials and processes. Hence, the designer's contribution, if sensitively considered in relation to context, can play a role in helping to restore complementarities and narrative unity and re-position outlooks and attitudes not least, by standing in contrast to predominant norms and asking us to reflect on these differences, the values they represent and their relationship to self, others and the world. 


\section{References}

Armstrong, K. (2002) Islam: A Short History, Phoenix Press, London.

Bakan, J. (2004) The Corporation: The Pathological Pursuit of Profit and Power, Constable and Robinson Limited, London.

Bassler, B. (2014) Exchanges at the Frontier, BBC World Service, first broadcast 19:06, 8 February.

Beckett, A. (2013) 'What is the 'global race'?', The Guardian, London, 22 September [online] http://www.theguardian.com/politics/2013/sep/22/what-is-global-race-conservatives-edmiliband (accessed 31 January 2014).

Bournville (n.d.) History of Bournville, Bournville Village Council, UK [online] http://bournvillevillagecouncil.org.uk/history-of-bourvnille/ (accessed 22 September 2014).

Brotton, J. (2006) The Renaissance, Oxford University Press, Oxford.

Chaibong, H. (2000) 'The cultural challenge of individualism', Journal of Democracy, Vol. 11, No. 1, pp.127-134, The Johns Hopkins University Press, Baltimore, MD.

Corfield, P.J. (2008) All People are Living Histories - Which is Why History Matters, Making History, School of Advanced Studies, Royal Holloway, University of London [online] http://www.history.ac.uk/makinghistory/resources/articles/why_history_matters.html (accessed 10 February 2014).

Davison, A. (2013) 'Making sustainability up: design beyond possibility', in Walker, S. and Giard, J. (Eds.): The Handbook of Design for Sustainability, Ch. 3, pp.43-56, Bloomsbury Academic, London.

Duffy, E. (1992) The Stripping of the Altars: Traditional Religion in England 1400-1580, Yale University Press, New Haven, CT.

Duffy, E. (2004) Faith of our Fathers: Reflections on Catholic Tradition, Continuum, London.

Dworkin, R. (2013) Religion without God, Harvard University Press, Cambridge, MA.

Edwards, B. (2012) Drawing on the Right Side of the Brain, Souvenir Press, London.

Fernández-Armesto, F. and Wilson, D. (1996) Reformation, Bantam Press, London.

Fioramonti, L. (2014) How Numbers Rule the World: The Use and Abuse of Statistics in Global Politics, Zed Books, London.

Fletcher, K. (2013) 'Sustainable fashion', in Walker, S. and Giard, J. (Eds.): The Handbook of Design for Sustainability, Ch. 18, pp.283-298, Bloomsbury Academic, London.

Fry, T. (2009) Design Futuring: Sustainability, Ethics and New Practice, Berg, Oxford.

Gay, P. (2007) Modernism: The Lure of Heresy from Baudelaire to Beckett and Beyond, Vintage Books, London.

Gray, L. (2012) 'Rio +20: Nick Clegg defies Tories again by pledging environment key to growth', The Telegraph, London, 15 June [online] http://www.telegraph.co.uk/earth/earthnews/ 9332404/Rio-20-Nick-Clegg-defies-Tories-again-by-pledging-environment-key-togrowth.html (accessed 31 January 2014).

Hague, W. (2007) William Wilberforce: The Life of the Great Anti-Slave Trade Campaigner, HarperCollins Publishers, London.

Hampson, N. (1968) The Enlightenment, Penguin Books, London.

Heidegger, M. (1971) translated by A. Hofstadter, Poetry, Language, Thought, HarperCollins, New York, NY.

Lansley, S. (1994) After the Gold Rush - The Trouble with Affluence, Century Business Books, London.

Leopold, A. (1949) A Sand County Almanac and Sketches Here and There, Oxford University Press, London. 
Lester, L. (2012) Risks and Rewards of Quantifying Nature's 'Ecosystem Services', Ecological Society of America [online] http://www.eurekalert.org/pub_releases/2012-06/esoarar062112.php\# (accessed 5 August 2013).

Lloyd, S. (Chair) (2013) RE: The Truth Unmasked - The supply of and support for Religious Education Teachers, An Inquiry by The All Party Parliamentary Group on Religious Education, March, Religious Education Council of England and Wales, London [online] http://religiouseducationcouncil.org.uk/images/stories/pdf/APPG_RE_The_Truth_Unmasked. pdf (accessed 3 March 2014).

Longley, C. (2013) 'Being very wealthy can, as Jesus pointed out, be bad for the soul', The Tablet, 10 August, London.

Longley, C. (2014) Thought for the Day, British Broadcasting Corporation, Radio 4, first broadcast 10 February [online] http://www.bbc.co.uk/programmes/p01s272q (accessed 15 March 2014).

Loos, A. (1900) The Poor Little Rich Man, in Spoken into the Void: Collected Essays 1897-1900, MIT Press, Cambridge, MA, Vol. 1982, pp.125-127.

Lutter, S. and Giljum, S. (2012) The Issue, World Resources Forum, Global Material Extraction and Resource Efficiency [online] http://www.worldresourcesforum.org/issue (accessed 14 August 2013).

MacCulloch, D. (2013) Silence: A Christian History, Allen Lane, Penguin Group, London.

MacIntyre, A. (2007) After Virtue, 3rd ed., Bristol Classical Press, Bloomsbury Academic, London.

Mau, B. (2004) Massive Chang: Massive Change: A Manifesto for the Future of Global Design: A Manifesto for the Future Global Design Culture, Phaidon Press, London.

McGilchrist, I. (2009) The Master and his Emissary: The Divided Brain and the Making of the Western World, Yale University Press, New Haven, CT.

Nagel, T. (2012) Mind and Cosmos: Why the Materialist, Neo-Darwinian Conception of Nature is Almost Certainly False, Oxford University Press, Oxford.

Odent, M. (2013) Childbirth and the Future of Homo Sapiens, Pinter \& Martin Ltd., London.

Pagels, E. (2006) The Gospel of Thomas: New Perspectives on Jesus' Message, a recorded lecture, Sounds True Inc., Boulder, CO, CD1, \#5.

Papanek, V. (1995) The Green Imperative: Natural Design for the Real World, Thames and Hudson, New York, NY.

Paton, G. (2014) 'Religious education subjected to 'rank discrimination', The Telegraph, 24 February [online] http://www.telegraph.co.uk/education/educationnews/10656555/ Religious-education-subjected-to-rank-discrimination.html (accessed 3 March 2014).

Pratt, V., Brady, E. and Howarth, J. (2000) Environment and Philosophy, Routledge, London [online] http://www.vernonpratt.com/thehumanbeing/individualism.htm (accessed 12 February 2014).

Reid, K. (2013) 'From fragmentation to wholeness', Resurgence and Ecologist, The Resurgence Trust, Bideford, Devon, UK, July/August, No. 279, pp.32-35.

Rodwell, J. (2013) Aesthetic \& Spiritual Responses to the Environment A two-day BESS workshop at York, 22/23 January 2013, Biodiversity \& Ecosystem Service Sustainability (BESS) Research Programme (2011-2017), Natural Environment Research Council (NERC), Report 3 July [online] http://www.nercbess.net/documents/BESS_NIA_Cultural_Ecosystem_Services_Workshop_Report.pdf (accessed 5 August 2013).

Said, E.W. (1978) Orientalism, 2003 ed., Penguin Books, London.

Said, E.W. (2003) 'Preface', in Said, E.W. (Ed.) (1978), Orientalism, 2003 ed., Penguin Books, London.

Schama, S. (2009a) A History of Britain, Vol. 2, The British Wars 1603-1776, The Bodley Head, London.

Schama, S. (2009b) A History of Britain, Vol. 1, At the Edge of the World? 3000 BC-AD 1603, TheBodley Head, London. 
Schama, S. (2009c) A History of Britain, Vol. 3, The Fate of Empire 1776-2000, The Bodley Head, London.

Schwaabe, C. (2011) Max Weber - The Disenchantment of the World, translated by J. Uhlaner, Goethe-Institute. V. [online] http://www.goethe.de/ges/phi/prt/en8250983.htm (accessed 14 February 2014).

Schwartz, B. (2004) The Paradox of Choice, HarperCollins, New York, NY.

Science Daily (2010) “Mitochondrial Eve': Mother of all humans lived 200,000 years ago: Rice University', Science Daily, 17 August [online] http://www.sciencedaily.com/releases/2010/08/ 100817122405.htm (accessed 15 March 2014).

Sprigg, J. and Larkin, D. (1987) Shaker: Life, Work and Art, Houghton Mifflin Company, Boston, MA.

Tarnas, R. (1991) The Passion of the Western Mind, Harmony Books, New York, NY.

Taylor, C. (2007) A Secular Age, The Belknap Press of Harvard University Press, Cambridge, MA.

Thompson, D.F. (1980) 'Moral responsibility of public officials: the problem of many hands', The American Political Science Review, December, Vol. 74, No. 4, pp.905-916, American Political Science Association, Washington, DC.

UNEP (2009) Facts and Figures: Global Materials Extraction (Figure 2.1), Resource Panel, United Nations Environment Programme [online] http://www.unep.org/resourcepanel/ FactsFigures/tabid/106638/Default.aspx (accessed 14 August 2013).

Wilkinson, R. and Pickett, K. (2009) The Spirit Level: Why More Equal Societies Almost Always do Better, Allen Land, Penguin Books, London.

Worldwatch Institute (2013) The State of Consumption Today, Worldwatch Institute, Washington DC [online] http://www.worldwatch.org/node/810 (accessed 14 August 2013).

Young, R.J.C. (2003) Postcolonialism, Oxford University Press, Oxford.

\section{Notes}

1 The word 'design' is being used to refer to a range of design disciplines - such as industrial design, furniture design and graphic design - that are typically taught in schools of art and design.

2 The Quakers, or Society of Friends, with their emphasis on communal silence, are something of an exception among the Protestant movements arising from the Reformation.

3 This European sense of positional superiority over other peoples, based on progress in science and technology and strongly connected to advancements in secularisation and democratic governance, is today being undermined by these very same developments. Firstly, the scientific capability of the West has revealed that all living humans have a common maternal ancestor - this is based on research in genetics at Rice University in the USA (Science Daily, 2010). Secondly, this discovery from 'secular', objective scientific inquiry has been given the name 'mitochondrial eve' after the first woman in the book of Genesis in the Abrahamic religious traditions, which essentially makes the same point about human origins. As Longley (2014) has said, this "shoots down every claim to racial superiority. I find it a pleasing irony that this basic ethical insight about humanity from the book of Genesis has now been confirmed by Darwinian evolutionary biology".

4 Material intensity refers to the economic output per unit of materials extraction.

5 In the early 1980s, the CEOs of large US companies were paid approximately 20 times more than their lowest paid workers; today, this has risen to ca. 280 times. This state of affairs reflects a significant failing of the consumer capitalist system. Not only are such gross disparities unjust, they also undermine social cohesion and social capital and create a drain on the economy [Longley, (2013), p.5]. Wilkinson and Pickett suggest that in many cases the disparity between CEO income and average worker income exceeds a ratio of 500:1 [Wilkinson and Pickett, (2009), pp.232, 243]. 